\title{
Peak expiratory flow in symptomless elderly smokers and ex-smokers
}

\author{
I Gregg, A J Nunn
}

\begin{abstract}
Values of peak expiratory flow (PEF) in 142 current smokers (116 men, 26 women) and 108 ex-smokers ( 88 men, 20 women) aged 55 or over were compared with the predicted values obtained in lifelong nonsmokers of the same age range. None of the subjects had been liable during childhood or subsequently to expectoration, lower respiratory tract infection, wheeze, or shortness of breath. Observed values of PEF were expressed as differences from predicted. Analysis of the relation between smoking state and ventilatory function in the men disclosed significant reductions of PEF in current smokers, the deficits increasing with the amount smoked from a mean of 48.1 $\mathrm{V} / \mathrm{min}$ in those smoking fewer than 20 cigarettes a day to $\mathbf{7 3 . 3} \mathrm{1} / \mathrm{min}$ in smokers of 20 or more a day. Significant reductions of PEF were also found in women who were currently smoking (mean $47.4 \mathrm{l} / \mathrm{min}$ ) and in male ex-smokers of 20 or more cigarettes a day (mean $27.8 \mathrm{l} / \mathrm{min}$ ). There was no significant reduction of PEF in male or female exsmokers of fewer than 20 cigarettes a day.

These findings suggest that factors besides smoking are concerned in the development of irreversible airflow obstruction.
\end{abstract}

\section{Introduction}

Identifying airflow obstruction and assessing its severity assume particular importance in the elderly by reason of the high prevalence of chronic bronchitis and emphysema in later life and the need to distinguish these from other respiratory and cardiovascular diseases, which cause dyspnoea by mechanisms other than airflow obstruction.

There is little reliable information about predicted values of peak expiratory flow (PEF) or forced expiratory volume in one second $\left(\mathrm{FEV}_{1}\right)$ in elderly people, in whom the necessity for deriving these from series which excluded smokers and ex-smokers ${ }^{1}$ is all the greater by reason of their generally prolonged exposure to the effects of smoking.

We have reported equations for the regression of PEF on age and height, which were derived from the findings in lifelong non-smokers who fulfilled strict criteria of normality.' In this paper we report the findings of a study in which these regressions were used to investigate ventilatory function in smokers and ex-

BrMed F 1989;298:1071-2

Age distribution and differences between observed and predicted peak expiratory flow (PEF) in normal subjects, ex-smokers, and current smokers

\begin{tabular}{|c|c|c|c|c|c|c|c|}
\hline \multirow[b]{2}{*}{ Subjects } & \multirow[b]{2}{*}{ No } & \multicolumn{2}{|c|}{ Age (years) } & \multicolumn{3}{|c|}{$\begin{array}{l}\text { PEF: difference between observed and } \\
\text { predicted }(1 / \mathrm{min})\end{array}$} & \multirow[b]{2}{*}{ p Value } \\
\hline & & Range & Mean & Range & Mean & $\begin{array}{l}\text { Standard } \\
\text { deviation }\end{array}$ & \\
\hline \multicolumn{8}{|l|}{ Men: } \\
\hline $\begin{array}{l}\text { Normal } \\
\text { Ex-smokers }\left\{\begin{array}{l}<20 / \text { day } \\
\geqslant 20 / \text { day }\end{array}\right.\end{array}$ & $\begin{array}{l}29 \\
40 \\
48\end{array}$ & $\begin{array}{l}55-79 \\
55-86 \\
55-81\end{array}$ & $\begin{array}{l}62 \cdot 3 \\
69 \cdot 8 \\
66 \cdot 2\end{array}$ & $\begin{array}{l}-90 \text { to } 93 \\
-126 \text { to } 83 \\
-131 \text { to } 113\end{array}$ & $\begin{array}{r}3 \cdot 4 \\
3 \cdot 6 \\
-27 \cdot 8\end{array}$ & $\begin{array}{l}50 \cdot 3 \\
66 \cdot 0 \\
67 \cdot 8\end{array}$ & $\begin{aligned} &- \\
&>0.25 \\
&<0.01\end{aligned}$ \\
\hline Current smokers $\left\{\begin{array}{l}<20 / \text { day } \\
\geqslant 20 / \text { day }\end{array}\right.$ & $\begin{array}{l}56 \\
60\end{array}$ & $\begin{array}{l}55-82 \\
55-87\end{array}$ & $\begin{array}{l}63 \cdot 4 \\
62 \cdot 9\end{array}$ & $\begin{array}{l}-268 \text { to } 42 \\
-214 \text { to } 82\end{array}$ & $\begin{array}{l}-48 \cdot 1 \\
-73 \cdot 3\end{array}$ & $\begin{array}{l}62 \cdot 9 \\
57 \cdot 9\end{array}$ & $\begin{array}{l}<0.001 \\
<0.001\end{array}$ \\
\hline \multicolumn{8}{|l|}{ Women: } \\
\hline $\begin{array}{l}\text { Normal } \\
\text { Ex-smokers }(<20 / \text { day })\end{array}$ & $\begin{array}{l}50 \\
20\end{array}$ & $\begin{array}{r}55-89 \\
55-83 \\
55-78\end{array}$ & $\begin{array}{l}67 \cdot 9 \\
66 \cdot 5 \\
62 \cdot 2\end{array}$ & $\begin{array}{l}-99 \text { to } 116 \\
-71 \text { to } 57\end{array}$ & $\begin{array}{r}-2 \cdot 6 \\
-12 \cdot 9 \\
-47 \cdot 4\end{array}$ & $\begin{array}{l}39 \cdot 5 \\
40 \cdot 7\end{array}$ & $\begin{array}{c}- \\
>0 \cdot 1 \\
<0.001\end{array}$ \\
\hline Current smokers $(<20 /$ day $)$ & 26 & $55-78$ & $63 \cdot 2$ & -123 to 52 & $-47 \cdot 4$ & $49 \cdot 5$ & $<0.001$ \\
\hline
\end{tabular}

$\star$ Paired $t$ test. smokers aged 55 or over who in all other respects would have been regarded as normal.

\section{Subjects and methods}

This study was part of a larger survey of adults of all ages carried out by one of us (IG) in general practices in Roehampton (south west London), Kingston upon Thames, and Southampton to elucidate the roles of smoking, respiratory infection, and other factors in the genesis and progression of irreversible airflow obstruction. ${ }^{2}$ The three practices were similar with respect to their social class composition and were in areas with generally low levels of atmospheric pollution.

Patients seen during routine consultations were questioned about smoking and liability to expectoration, respiratory infection, wheeze, or shortness of breath during childhood and adulthood. Inquiry was made about the ages at which subjects had begun to smoke and, in the case of ex-smokers, when they had stopped, but the information obtained was too imprecise for analysis.

Male and female smokers and ex-smokers aged 55 or over who denied having ever had any of the above symptoms and whose case records disclosed no history of respiratory or cardiac disease were included in the study. They were classified as ex-smokers-that is, people who had given up smoking at least one year previously - ( 88 men, 20 women) and current smokers (116 men, 26 women). They were assigned to one of two categories according to their estimated average lifetime smoking consumption as follows: light smokers-namely, people smoking fewer than 20 cigarettes a day or an equivalent amount of tobacco in hand rolled cigarettes or pipes ( $14 \mathrm{~g} \simeq 15$ cigarettes) and heavy smokers-namely, people smoking 20 or more cigarettes (or equivalent) a day. None of the women smokers or ex-smokers admitted to having smoked as many as 20 cigarettes a day.

All measurements of PEF were made with a Wright peak flow meter and were carried out by a single observer (IG) as described (accompanying paper). ${ }^{1}$ The findings were expressed as differences between observed and predicted values, predicted values being obtained from new regression equations of PEF on age and height.

The relation between smoking state and ventilatory function was examined by analysis of the differences between observed and predicted PEF in the various smoking categories.

\section{Results}

The table gives the age distributions of the subjects in each smoking category and the ranges, means, and standard deviations of the differences between their observed and predicted values of PEF. The table also shows these variables in non-smokers of similar age range, who were part of the series from which the predicted values were obtained.'

Paired $t$ tests disclosed a highly significant association between smoking state and reduction of PEF. The magnitude of the reduction increased with average lifetime smoking consumption and was largest in subjects who were currently smoking. 
The mean deficits in PEF in men and women smoking fewer than 20 cigarettes a day were $48 \cdot 1$ and $47.4 \mathrm{l} / \mathrm{min}$, respectively. In men smoking 20 or more a day the mean deficit was $73.3 \mathrm{l} / \mathrm{min}$. A smaller but still significant deficit $(27 \cdot 8 \mathrm{1} / \mathrm{min})$ was found in male exsmokers of 20 or more cigarettes a day, whereas in the male and female ex-smokers of fewer than 20 cigarettes a day no significant reduction of PEF was present.

Even in the group of 60 men who were currently smoking 20 or more cigarettes a day only five had observed values that were more than $150 \mathrm{l} / \mathrm{min}$ below predicted.

\section{Discussion}

Other workers have drawn attention to the paucity of knowledge concerning ventilatory function in elderly people. ${ }^{3-5}$ Reference values which are commonly used for predicting PEF or $\mathrm{FEV}_{1}$ above the age of 60 have been derived by extrapolation of linear regressions in younger subjects. ${ }^{6-10}$ For instance, those which Cotes advocated for predicting PEF in men" were obtained in a series containing only three men aged over $60,{ }^{9}$ and those for women were from a series of 64 women whose ages ranged between 19 and $82^{10}$; both series included a high proportion of smokers.

Owing to the comparatively small number of lifelong non-smokers aged over $60,{ }^{13}$ particularly among men, most other workers who have investigated ventilatory function in the elderly have included smokers and exsmokers, provided that they appeared healthy, denied expectoration, and gave no history of respiratory or cardiac disease. ${ }^{3512-15}$ Even so, in one study of $\mathrm{FEV}_{1}$ in randomly selected and apparently healthy men aged $62-90$, of whom $92 \%$ were or had been smokers, persistent cough and phlegm were found to be present in one third. ${ }^{3}$

In a survey of PEF and $F_{1} V_{1}$ in subjects aged 65-94 only three of 83 men were non-smokers ${ }^{13}$ whereas in a more recent study of 46 men aged $60-85$ fewer than a third had never smoked. ${ }^{\text {s }}$

We did not adopt the frequently used convention of expressing observed values as percentages of predicted, as there is no physiological or statistical validity in regarding a given percentage of predicted as representing the lower limit of normal. ${ }^{16}$ Instead, we expressed our findings of PEF as differences between subjects' observed and predicted values.

Other workers have shown that the PEF can discriminate between "healthy" men aged over 50 and those with "mild" chronic bronchitis. ${ }^{18}$ Our findings, however, indicate that smoking can cause significant impairment of ventilatory function in the absence of hypersecretion of mucus.
It was not a principal aim of this study to investigate the role of smoking in the pathogenesis of chronic bronchitis; indeed, our selection criteria excluded people with even "simple chronic bronchitis". ${ }^{19}$ Nevertheless, our finding that the reduction of PEF in smokers and former heavy smokers, though highly significant, was much smaller than that which is characteristic of patients with advanced chronic bronchitis or emphysema suggests that other factors besides smoking are concerned in the development of severe, irreversible airflow obstruction and dyspnoea. It seems probable that these include hypersecretion of mucus in small airways and susceptibility during childhood or adulthood to recurrent lower respiratory tract infection or asthma. By reason of the selection criteria that we used, none of these factors had been operative in the subjects whom we studied.

We thank Miss Deborah Johnson and Mrs Marion Rickman for their help in analysing the data, and the Rudolf Friedlaender Memorial Trust, the Department of Health and Social Security, the Royal College of General Practitioners, and Allen and Hanbury's Ltd for grants which supported this study.

1 Nunn AJ, Gregg I. New regression equations for predicting peak expiratory flow in adults. Br Med f 1989;298:1068-70.

2 Gregg I. A study of the causes of progressive airways obstruction in chronic bronchitis. In: Proceedings of llth Aspen emphysema conference. Arlington, Virginia: US Department of Health, Education and Welfare, 1969:235-46.

3 Milne JS, Williamson J. Respiratory function tests in older people. Clin Sci 1972:42:371-81.

4 Morris JF, Koski A, Johnson LC. Spirometric standards for healthy nonsmoking adults. Am Rev Respir Dis 1971;103:57-67.

5 Schmidt CD Dickman ML, Gardner RM, Brough FK Spirometric standards for healthy elderly men and women. Am Rev Respir Dis 1973;108:933-9.

6 Gregg I, Nunn AJ. Peak expiratory flow in normal subjects. Br Med $\mathrm{f}$ 1973; iii:282-4.

7 Kory RC, Callahan R, Boren HG, Syner JC. The Veterans Administration Army Cooperative study of pulmonary function. 1. Clinical spirometry in normal men. Am f Med 1961;30:243-58.

8 Berglund E, Birath G, Biore J, et al. Spirometric studies in normal subjects. Forced expirograms in subjects between 7 and 70 years of age. Acta Med Scand 1963;173:185-92.

9 Leiner GC, Abramowitz S, Small MJ, Stenby VB, Lewis WA. Expiratory peak flow rate. Standard values for normal subjects. Use as a clinical test of ventilatory function. Am Rev Respir Dis 1963;88:644-51.

10 Pelzer AM, Thomson ML. Expiratory peak flow. Br Med f 1964;ii: 123.

11 Cotes JE. Lung function: assessment and application in medicine. 4th ed. Oxford Blackwell Scientific, 1979.

12 Ericsson $\mathrm{P}$, Irnell $\mathrm{L}$. Spirometric studies of ventilatory capacity in elderly people. Acta Med Scand 1969;185:179-84.
pericsson P, Irnell L. Spirometric studies of

13 Caird FI, Akhtar AJ. Chronic respiratory disease in the elderly: a population study. Thorax 1972;27:764-8

14 Burr ML, Phillips KM, Hurst DN. Lung function in the elderly. Thorax 1985; $40: 54-9$

15 Fowler RW, Pluck RA, Hetzel MR. Maximal expiratory flow-volume curve in Londoners aged 60 years and over. Thorax 1987;42:173-82.

16 Sobol BJ, Sobol P. Per cent of predicted as the limit of normal in pulmonary function testing: a statistically valid approach. Thorax 1979;34:1-3.

17 Miller MR, Pinock AC. Predicted values: How should we use them? Thorax 1988:43:265-7.

18 Flint FJ, Khan MO. Clinical use of peak flow meter. Br Med $\mathcal{f}$ 1962;ii:1231-3.

19 Medical Research Council. Definition and classification of chronic bronchitis for clinical and epidemiological purposes. Lancet 1965;i:775-9.

(Accepted 27 February 1989)
Department of Urology, Southmead Hospital, Bristol K M Desai, CHM, senior registrar J C Gingell, FRCS, consultant

Correspondence to: Mr Desai.

BrMed F 1989;298:1072-3

\section{Hazards of long distance cycling}

\section{K M Desai, J C Gingell}

We report an unusual complication of long distance cycling that occurred in a young man unaccustomed to riding more than a few kilometres.

\section{Case report}

An otherwise healthy 27 year old man was referred to us because of secondary erectile impotence. He had enjoyed normal sexual function before taking part in a two day, $209 \mathrm{~km}$ bicycle race five months previously. He had ridden on a narrow, hard leather saddle and had experienced severe perineal pain and urgency of micturition after cycling about $32 \mathrm{~km}$, which had forced him to stop at a service station. While voiding he had noticed that his penis was completely shrivelled and had lost all sensation. The pain subsided after a few minutes, enabling him to continue cycling. $\mathrm{He}$ managed to finish the race despite recurrence of perineal and gluteal pain causing further brief stops. After the race he suffered a total loss of erections for about three weeks. By the time he was seen in our clinic his erections had gradually improved, but they still lacked full rigidity and were only briefly sustained. $\mathrm{He}$ also complained of impaired penile sensation, though this too had partially recovered. Orgasmic sensation and ejaculation were allegedly normal.

Results of clinical examination and routine analysis of urine, a random blood glucose concentration, and serum testosterone and prolactin concentrations were normal. An intracavernosal injection of $15 \mathrm{mg}$ 